\title{
Spatial variation in vital rates and population growth of thick-billed murres in the Atlantic Arctic
}

\author{
Morten Frederiksen ${ }^{1, *}$, Sébastien Descamps ${ }^{2}$, Kyle H. Elliott ${ }^{3}$, Anthony J. Gaston ${ }^{4}$, \\ Nicholas P. Huffeldt ${ }^{1,5}$, Yann Kolbeinsson ${ }^{6}$, Jannie Fries Linnebjer ${ }^{1}$, Erlend \\ Lorentzen $^{2}$, Flemming R. Merkel ${ }^{1,5}$, Hallvard Strøm², Thorkell Lindberg Thórarinsson ${ }^{6}$ \\ ${ }^{1}$ Department of Bioscience, Aarhus University, 4000 Roskilde, Denmark \\ ${ }^{2}$ Norwegian Polar Institute, Fram Centre, 9296 Tromsø, Norway \\ ${ }^{3}$ Canada Research Chair in Arctic Ecology, Department of Natural Resource Sciences, McGill University, Montreal, \\ QC H9X 3V9, Canada \\ ${ }^{4}$ Environment and Climate Change Canada, Ottawa, ON K1A 0H3, Canada \\ ${ }^{5}$ Greenland Institute of Natural Resources, 3900 Nuuk, Greenland \\ ${ }^{6}$ Northeast Iceland Nature Research Centre, 640 Húsavík, Iceland
}

ABSTRACT: Understanding spatiotemporal variation in vital rates and population growth rates is a central aim of population ecology, and is critical to conservation of migratory species where different populations may spend the non-breeding season in sometimes widely separated areas. However, estimating those parameters and identifying the underlying drivers of variation for species migrating to remote areas is challenging. The thick-billed murre Uria lomvia is a colonial seabird with a pan-Arctic distribution. Previous studies have documented large-scale spatial variation in population growth in the species' Atlantic range, with eastern populations declining and western populations being stable, and suggested that this variation was linked to conditions in the wintering areas. We analyse variation in breeding success and adult survival from colonies throughout the Atlantic range, construct region-specific stochastic population models, and compare model predictions to observed colony growth rates. Breeding success was uniformly high in Greenland and Iceland, lower and more variable in Spitsbergen, Bjørnøya and Hudson Bay, and low at Jan Mayen. Adult survival was average or high in all colonies during the 2010s. Observed colony growth rates were lower than modelled growth rates for most populations. This suggests that pre-breeding survival or breeding propensity must have been lower than assumed in many of these populations. Low pre-breeding survival could be linked to poor feeding conditions in fall and winter, possibly influenced by large-scale oceanographic variation. Our results support the idea that seabird populations not

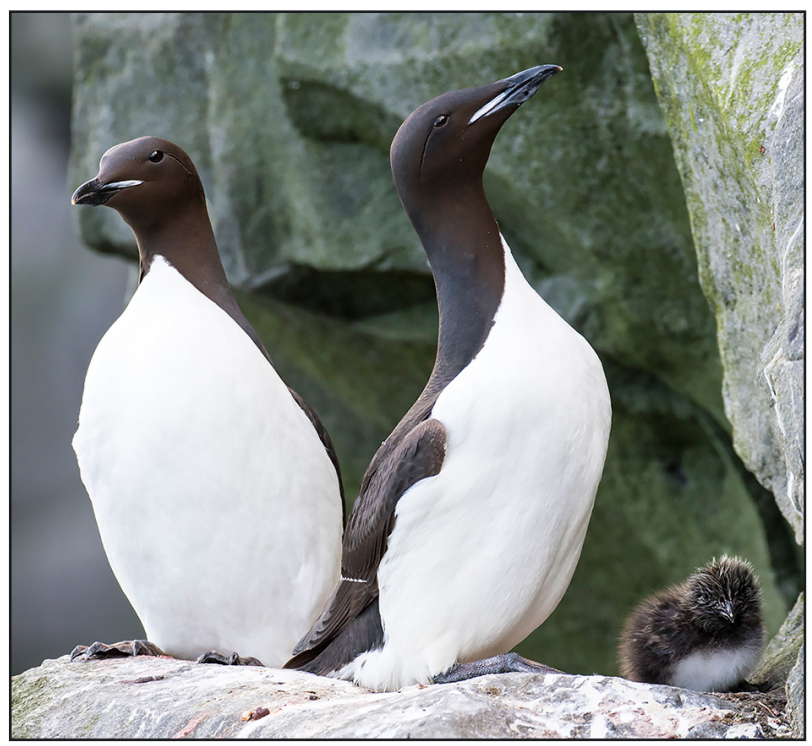

A pair of thick-billed murres Uria lomvia attending their single chick on a cliff ledge in Iceland.

Photo: Yann Kolbeinsson

subject to breeder mortality due to anthropogenic causes are regulated mainly through variation in pre-breeding survival.

KEY WORDS: Demography · Adult survival · Prebreeding survival $\cdot$ Breeding success $\cdot$ Colony growth rates $\cdot$ Seabird $\cdot$ Uria lomvia $\cdot$ Brünnich's guillemot

(C) The authors and The Crown in the Right of Canada 2021 Open Access under Creative Commons by Attribution Licence. Use, distribution and reproduction are unrestricted. Authors and original publication must be credited.

Publisher: Inter-Research · www.int-res.com 


\section{INTRODUCTION}

Most animal species show extensive spatial variation in vital rates, most importantly survival and reproductive output, and rate of population change or growth (Bjørnstad et al. 1999, Frederiksen et al. 2005). Such variation occurs on scales ranging from very local (Tavecchia et al. 2008, Sanz-Aguilar et al. 2009) to global (Irons et al. 2008, Suryan et al. 2009). For some species, interannual variability in vital rates or population growth is synchronised over relatively large spatial scales (Liebhold et al. 2004), while others show extensive spatial variation with little or no synchrony (Cayuela et al. 2020, Descamps et al. 2020). However, the underlying causes of spatial variation in population trends are often unclear.

Several mechanisms have been proposed to explain spatial variation in vital rates. Underlying large-scale gradients in primary productivity may affect vital rates and life history variation across several trophic levels, e.g. between ocean basins (Suryan et al. 2009). Large-scale interannual climatic variation, often summarised in derived indices such as the Southern Oscillation Index, has in some cases been shown to synchronise demographic variation over large scales (Jenouvrier et al. 2009). However, observed patterns of spatial demographic variation are often difficult to reconcile with such large-scale paradigms (Ringsby et al. 2002, Pironon et al. 2017, Tjørnløv et al. 2020) and are more reflective of relatively local-scale variation in e.g. habitat suitability (Ens et al. 1992), predation pressure (Ekroos et al. 2012), or anthropogenic impacts (Lee et al. 2016). For migratory species, conditions on the wintering grounds may have a strong impact on survival and thus lead to differences and similarities (e.g. synchrony) among populations (Gaston 2003, Reneerkens et al. 2020).

A good understanding of spatial variation in vital rates, and the environmental factors driving this variation, is particularly important for species of conservation or management concern (Johnson et al. 2010). For such species, successful management relies on understanding current vital rates and the possibilities of modifying them (Norris 2004). If population trends, vital rates or the factors affecting them show substantial spatial variation, managers need to be aware of this and target their actions appropriately. Spatial scale is particularly important for transboundary management efforts, as population change driven by large-scale processes may not be responsive to local management efforts (Dallimer \& Strange 2015, Harrison et al. 2018).
For seabirds, there are 2 main hypotheses regarding population regulation. Ashmole (1963, see also Birt et al. 1987, Elliott et al. 2009) suggested that seabird colony size is regulated by prey availability during the breeding season because birds deplete prey resources near the colony and travel distance thus increases with colony size, which sets a limit to reproduction. On the other hand, Lack (1966) suggested that prey availability during the non-breeding season is more likely to regulate population size because of the generally lower productivity and thus availability of prey at this time of year. We suggest that variation in vital rates and population growth between seabird populations wintering in different areas would support Lack's view.

The thick-billed murre (or Brünnich's guillemot) Uria lomvia is an abundant colonial seabird with a panArctic distribution (Gaston \& Hipfner 2020). Thickbilled murres are long-lived, and pairs produce a maximum of 1 chick annually, which leaves the colony when less than half grown accompanied by the male parent (Gaston \& Jones 1998). Males provide postfledging parental care for several weeks (Elliott et al. 2017). Many murre populations in the Atlantic Arctic are declining rapidly, particularly those in Svalbard, Iceland and a large part of Greenland, which mainly overwinter off southwest Greenland and around Iceland (Frederiksen et al. 2016). At the same time, populations breeding in Canada and northwest Greenland, and wintering off the Atlantic coast of Canada, seem to be stable (reviewed in Frederiksen et al. 2016). Potential drivers of the observed declines include climate-driven deterioration of winter food supply (Descamps et al. 2013, Fluhr et al. 2017), mercury pollution (Albert et al. 2021), and direct anthropogenic mortality due to hunting and oil pollution (Frederiksen et al. 2019). However, the relative role of these and other drivers, and the causes of the observed large-scale variation in population trends, remain poorly understood. Populations across the Canadian Arctic fluctuated synchronously in the late $20^{\text {th }}$ century, presumably because populations were regulated via mechanisms, possibly harvest, on their common wintering grounds (Gaston 2003).

Until recently, information on vital rates of thickbilled murres was limited to a few long-term studies, e.g. at Coats Island in Hudson Bay (Gaston et al. 1994) and Bjørnøya in Svalbard (Fluhr et al. 2017). However, recent expansions of monitoring efforts in Greenland, Iceland and Norway (Jan Mayen and Spitsbergen) have provided a much broader picture of demographic variation. Here, we collate and analyse the recent (mainly since 2010) available data on 
adult survival and reproductive output from colonies throughout the Atlantic range of the species. We estimate means and temporal variation for each colony, and use the results to construct demographic projection models for each regional population. Finally, we compare the projected growth rates to observed regional population trends and discuss potential demographic and ecological mechanisms behind the observed spatial variation in demography and population trends.

\section{MATERIALS AND METHODS}

\subsection{Study sites and regions}

Breeding success and population size were monitored at 12 colonies in Canada, Greenland, Iceland and Norway (Jan Mayen, Spitsbergen and Bjørnøya), and adult survival was monitored at 6 of these colonies (Table 1, Fig. 1; see Section 2.4, 2nd paragraph, for Iceland). Most time series started after 2005 (Table 1), but monitoring of at least 1 parameter was initiated at Coats Island, Canada in 1990 and at Bjørnøya, Svalbard in 1986. Based on biogeographic and ecological differences in breeding and wintering areas, as well as data availability, we grouped the study sites into 6 regions: Canada, Greenland, Iceland, Jan Mayen, Spitsbergen and Bjørnøya.

\subsection{Colony growth}

The mean growth rate of each study colony during the 2010s was estimated based on available plot, transect or complete counts of murres present in the colony (Table 1). For each colony separately, counts were regressed against year (for Bjørnøya with an additive effect of plot to allow for missing plot counts in some years), with a log link function and quasi-Poisson errors. The regression coefficients were back-transformed to the real scale for comparison with modelled growth rates.

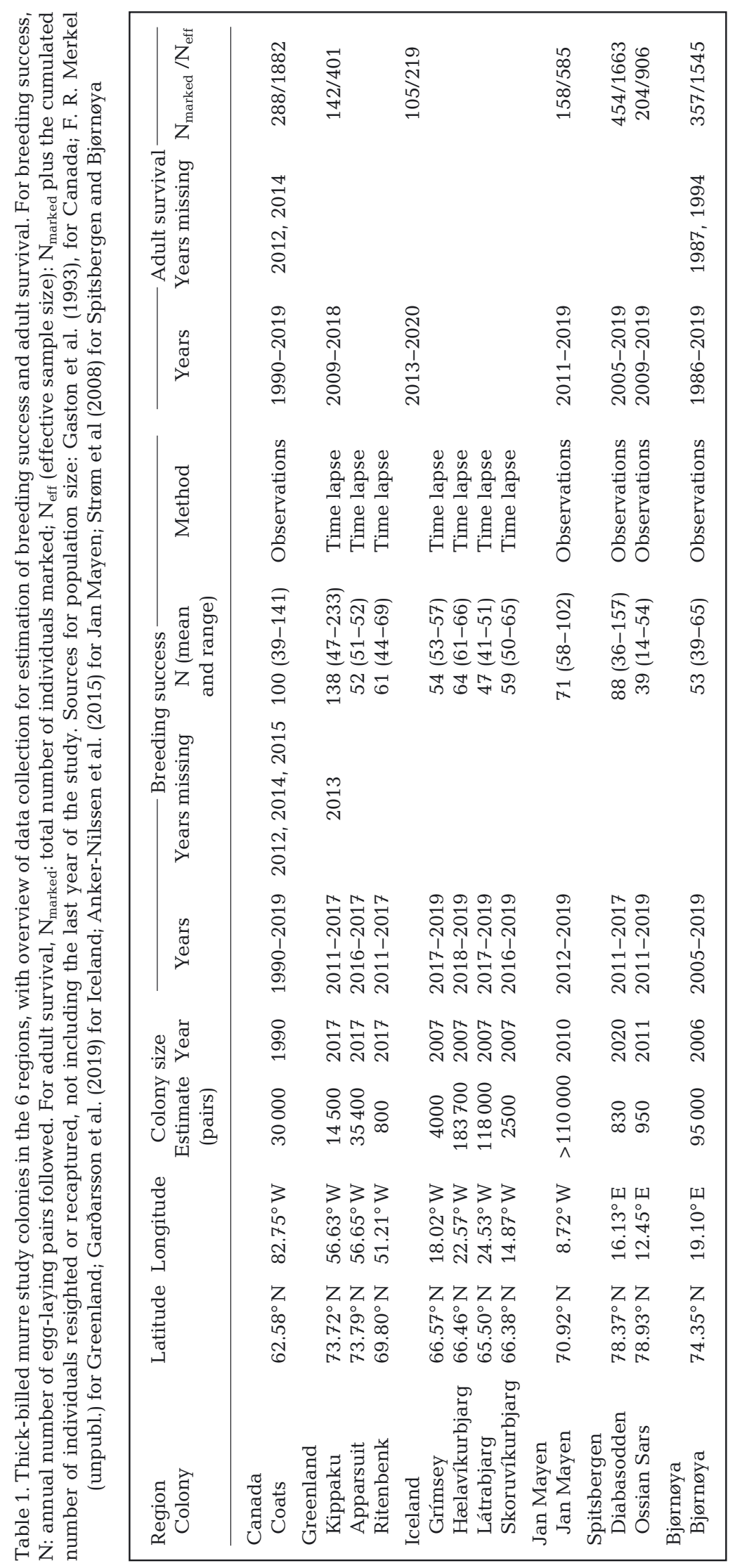




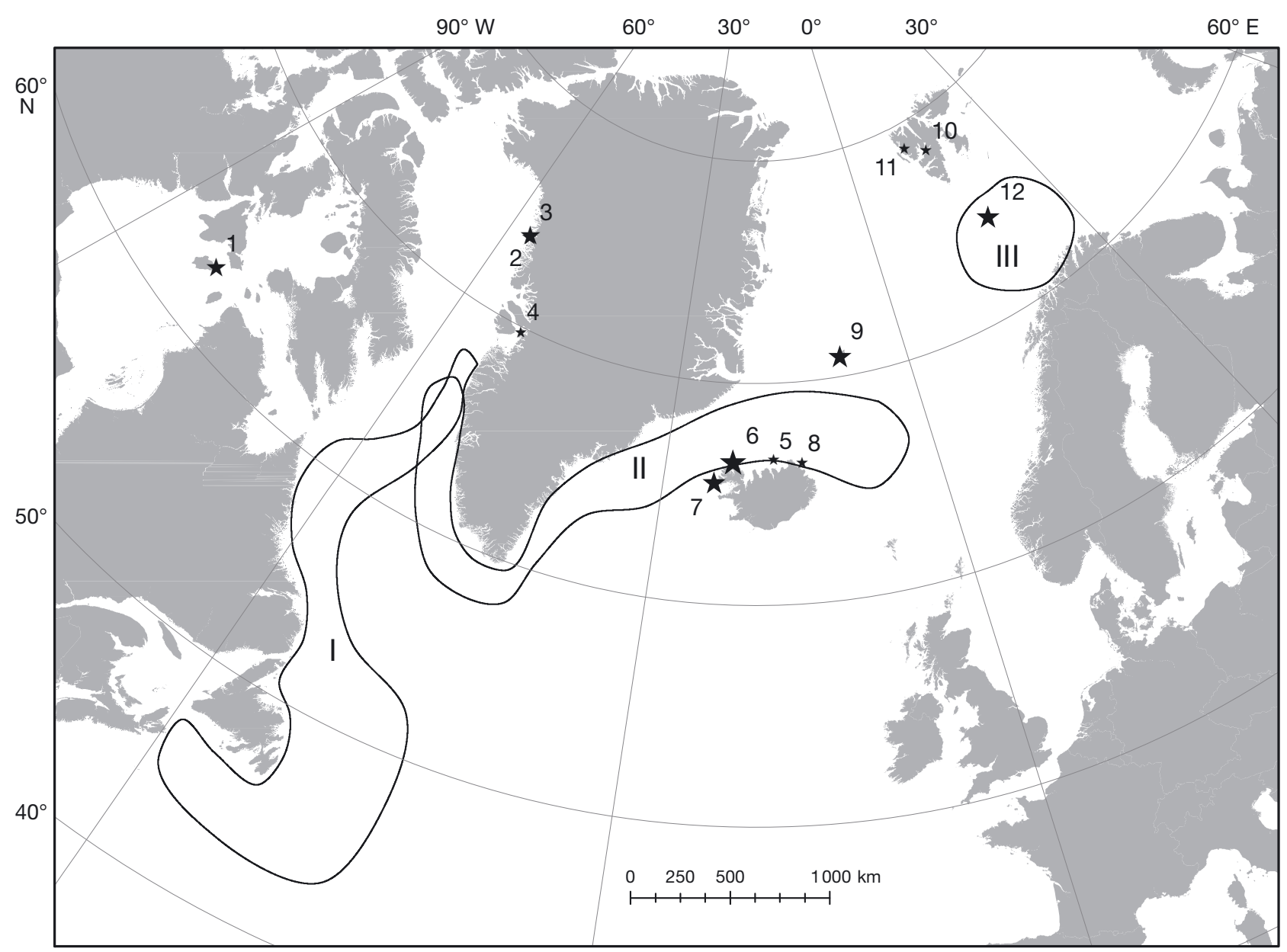

Fig. 1. Study area and thick-billed murre colonies (1-12, with size of $\star$ indicating colony size, see Table 1) included in this study. 1: Coats, 2: Kippaku, 3. Apparsuit, 4: Ritenbenk, 5: Grímsey, 6: Hælavíkurbjarg, 7: Látrabjarg, 8: Skoruvíkurbjarg, 9: Jan Mayen, 10: Diabasodden, 11: Ossian Sarsfjellet, 12: Bjørnøya. Polygons: generalised wintering areas (I-III) based on Frederiksen et al. (2016) and SEATRACK (https://seapop.no/en/seatrack/, accessed 15 June 2021). Murres from Canada and northwest Greenland use wintering area I, those from Iceland, Jan Mayen and West Spitsbergen use II, while those from Bjørnøya use III and the eastern part of II

\subsection{Breeding success}

Breeding success, i.e. the proportion of eggs laid that resulted in a 'fledged' chick, was estimated using either traditional methods where observers recorded the fate of each egg in dedicated plots (Walsh et al. 1995) at Coats, Jan Mayen, Spitsbergen and Bjørnøya, or time-lapse photography following Merkel et al. (2016) in Greenland and Iceland. At Kippaku, Greenland, 2 time-lapse plots were used. Observers usually arrived at study colonies during early to mid-incubation and sometimes left before all chicks had departed, and some early egg losses or late chick losses may therefore have been missed. Time-lapse photography was not affected by this limitation, as monitoring of nest sites was initiated before egg laying and extended until all birds had left the plots. See Table 1 for details.

Stochastic matrix models (see Section 2.5) require unbiased (i.e. unaffected by sampling error) estimates of between-year variation in demographic parameters. We used a variance components approach (Link \& Nichols 1994, Gould \& Nichols 1998) to estimate process variance (i.e. between-year variation corrected for sampling error) for each decade, assuming zero covariance between years or colonies: $\operatorname{Var}_{\text {process }}=$ $\operatorname{Var}_{\text {between-year }}-\frac{1}{n} \sum_{i=1}^{n} \operatorname{Var}_{i}$, where $i$ indicates the $n$ annual estimated means, and $\operatorname{Var}_{i}$ is affected only by sampling error. When several colonies were monitored in 1 region (Greenland, Iceland and Spitsbergen), we also included between-colony variation in process variance. 


\subsection{Adult survival}

Breeding thick-billed murres were captured using a noose on an extendable $(4-8 \mathrm{~m})$ fishing rod, and marked with individually coded engraved plastic or metal rings, or individual colour ring combinations, in dedicated observation plots in Canada (Coats), Greenland (Kippaku), Jan Mayen, Spitsbergen (2 colonies) and Bjørnøya (Table 1). Resightings were carried out during incubation and/or chick rearing by experienced observers from hides or fixed vantage points (up to $50 \mathrm{~m}$ from plots), using binoculars or telescopes with zoom oculars. Annual encounter histories were compiled from the marking and resighting data.

No colour-ringing data were available for Iceland. Instead we used capture-recapture data from breeding murres tagged with light loggers at 3 colonies (Látrabjarg, Grímsey and Langanes (incl. Skoruvíkurbjarg)) (Linnebjerg et al. 2018, www.seapop.no/ en/seatrack/). Birds released without loggers were removed from the sample (i.e. treated as losses on capture), and entered as new individuals if they were tagged again in subsequent years. In this way, estimated recapture probabilities only refer to birds carrying loggers. Birds tagged on ledges that were subsequently deserted by breeding murres were not included (40 of 145 murres tagged in 2013-19 were excluded). Data from the 3 colonies were pooled, because numbers released were low and recapture effort was similar between colonies.

Capture-recapture/resighting data were analysed using live encounter models in MARK 9.0 (White \& Burnham 1999). Goodness of fit to the standard Cormack-Jolly-Seber model (Lebreton et al. 1992) was tested in U-CARE 2.3.4 (Choquet et al. 2009). In all cases, the directional test for trap-dependence was highly significant, indicating trap-happiness, i.e. animals observed in the previous year were more likely to be observed in the current year than those not observed. Trap-happiness likely reflects some breeding sites being more visible or accessible than others due to cliff topography, in combination with extremely high site fidelity (Harris et al. 1996) and between-individual variation in behaviour and thus observability. To account for this, we used multi-state models with a dummy state for unobserved birds, with survival constrained to be the same for observed and unobserved birds (Gimenez et al. 2003). In these models, nominal resighting probabilities are fixed to respectively 1 and 0 , and real resighting probabilities are estimated as transition probabilities between the 2 states (high and low observability). Resighting probabilities of the 2 states were constrained to vary in parallel over time (additive model, Pradel 1993). Goodness of fit of the model with additive trap-dependence was tested using the median c-hat procedure in MARK, and a variance inflation factor was applied if necessary.

We fitted models where survival was constrained to be either constant over time, varying from year to year, or varying among decades (1980s, 1990s, 2000s, 2010s). The decadal model was designed to allow comparison of recent mean survival between time series of widely differing lengths (Table 1). All models had year-to-year variation in resighting probability, with an additive effect of trap-dependence. We used the variance components approach in MARK to estimate mean survival, standard error of the mean, and process variance (i.e. between-year variation corrected for sampling error) for each decade with available data, based on the model with year-to-year variation in survival. Process variance was estimated for the entire time series. The last estimate of survival in a time series is not separately identifiable in fully timedependent models and was for this reason not included in the variance components procedure. In Spitsbergen, 2 time series of adult survival were available, and we combined the estimated means from the 2 colonies assuming independence (i.e. zero sampling covariance) as for breeding success (Section 2.2).

\subsection{Population model}

We constructed stochastic matrix projection models with a pre-breeding census (Caswell 2001) for each region in R 3.6.2 (R Core Team 2019). The models were parameterised using region-specific means and process variances of breeding success and adult survival for the 2010s. In the absence of regionspecific empirical estimates, values of other demographic parameters were set to be the same in all regions and taken from the literature (Wiese et al. 2004, Harris et al. 2007) or assumed; see Table 2. Two scenarios were run for non-observed parameters, 1 basic (optimistic) and 1 more pessimistic, i.e. with lower parameter values (Table 2). The model was run for 10 years using 10000 stochastic simulations. Model simulations accounted for both sampling error, i.e. uncertainty of mean values of demographic variables, and environmental stochasticity, i.e. process variance. In each simulation, mean values of breeding success and adult survival were drawn from a beta distribution with the overall region-specific mean and standard error of the mean. Year-specific values of these parameters were then drawn from a beta distribution with the simulation-specific mean 
Table 2. Parameters of the stochastic projection model. Apart from thick-billed murre adult survival and breeding success, parameter values used were the same in all regions. Values of demographic parameters were assumed when no empirical information was available

\begin{tabular}{|lccc|}
\hline Parameter & Mean (basic/pessimistic) & Process variance (assumed) & Source \\
\hline First-year survival & $0.56 / 0.50$ & 0.01 & Harris et al. (2007) \\
Second-year survival & $0.79 / 0.75$ & 0.0025 & Harris et al. (2007) \\
Third-year survival & $0.90 / 0.85$ & 0.0025 & Assumed \\
Fourth-year survival & $0.92 / 0.90$ & 0.0025 & Assumed \\
Adult survival (fifth year and older) & See Fig. 3 & See Fig. 3 & Present study \\
Proportion breeding, 3 yr old & $0.025 / 0$ & 0 & Wiese et al. (2004) \\
Proportion breeding, 4 yr old & $0.367 / 0$ & 0 & Wiese et al. (2004) \\
Proportion breeding, 5 yr old & $0.700 / 0.50$ & 0 & Wiese et al. (2004) \\
Proportion breeding, 6 yr and older & $0.985 / 0.90$ & 0 & Wiese et al. (2004) \\
Breeding success & See Fig. 2 & See Fig. 2 & Present study \\
Sex ratio & 0.5 & 0 & Assumed \\
\hline
\end{tabular}

and a standard error derived from the estimated process variance. For pre-breeding survival, values were drawn from beta distributions with a mean taken from the literature and an assumed process variance (Table 2). Values of age-specific proportions of breeders and sex ratio were deterministic in the model (Table 2). Simulations were initialised with a stable age distribution based on the overall regionspecific mean parameter values, derived using the $\mathrm{R}$ package popbio (Stubben \& Milligan 2007). Stochastic annual growth rate was calculated for each simulation as $\sqrt[10]{N_{\text {end }} / N_{\text {start }}}$, where $N$ is the total population summed over all age classes.

\section{RESULTS}

\subsection{Breeding success}

Mean breeding success during the 2010s varied between regions, from 0.40 to 0.78 chicks pair $^{-1}$ (Fig. 2). No complete breeding failures were observed in 70 colony-years (nor in 22 seasons prior to 2010 at Coats, Canada, or in 5 seasons prior to 2010 at Bjørnøya), and annual estimates varied from 0.16 to 0.92 chicks pair $^{-1}$ (Fig. S1 in the Supplement at www.int-res. com/articles/suppl/m672p001_supp.pdf). Breeding success during the 2010s was highest, most stable (lowest process variance) and most precisely estimated (lowest standard error of the mean) in Greenland and Iceland, lowest at Jan Mayen, and most variable in Canada (Fig. 2).

\subsection{Adult survival}

Results of goodness-of-fit tests are shown in Table S1 in the Supplement. The directional $z$-test for trap-happiness was highly significant in all colonies $\left(-9.6<z<-2.4,6 \times 10^{-22}<\mathrm{p}<0.015\right)$, whereas the median $\mathrm{c}$-hat test of the model with additive trapdependence showed little sign of remaining lack of fit (c-hat $<1.25$ in all cases). The best model for describing adult survival probability varied among colonies (Table 3). In some colonies, there was substantial between-year (Coats) and between-decade (Bjørnøya) variation, whereas survival in other colonies was much more stable (Fig. S2 in the Supplement). The lowest annual estimate (0.58) occurred at Bjørnøya in 2007/08, and the lowest decadal mean (0.82) at Bjørnøya during the 2000s.

Mean adult annual survival probability during the 2010s was fairly similar among regions, varying from 0.93 at Bjørnøya to 0.88 at Spitsbergen (Fig. 3). Between-year variation was highest in Iceland and lowest at Spitsbergen.

\subsection{Population growth}

The mean projected annual population growth rate varied among regions (Fig. 4), being lowest (0.976) at Jan Mayen and highest (1.036) in Iceland. In the more pessimistic scenario with lower values of prebreeding survival and breeding propensity, mean projected growth rates ranged from 0.958 (Jan Mayen) to 1.008 (Iceland). Projected growth rates were most variable in Iceland (Fig. 4), where process variation and standard error of the mean were highest for adult survival.

In 10 of the 12 study colonies, the observed annual growth rate was $<1$, i.e. colonies declined in size over the 2010s (Fig. S3 in the Supplement). Observed growth rates ranged from 0.86 at Jan Mayen to 1.02 at Kippaku (Greenland). In most cases, observed growth rates were lower than pro- 
Fig. 2. Estimates of mean breeding success (chicks fledged per egg-laying pair) of thick-billed murres during the 2010s (top panel), standard error of the mean (middle panel), and process variance (between-year variation excluding sampling error; lower land, Iceland and Spitsbergen represented by respectively 3,4 and 2 study colonies; Canada represented by 1 colony (Coats) panel) in the 6 regions. Green-
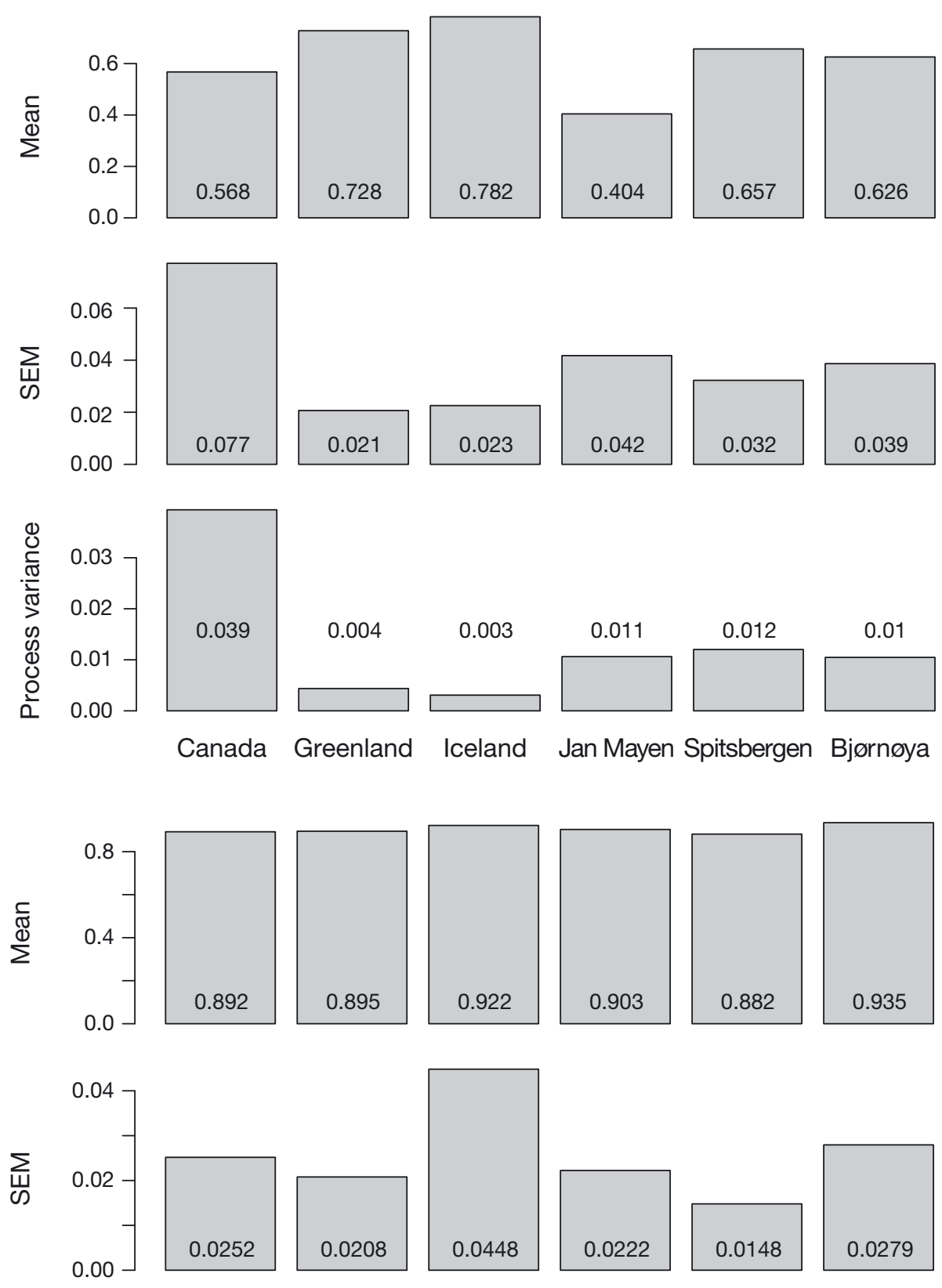

Fig. 3. Estimates of mean adult annual survival probability of thick-billed murres during the 2010s (top panel), standard error of the mean (middle panel), and process variance (between-year variation excluding sampling error; lower panel) in the 6 regions. Iceland and Spitsbergen represented by respectively 3 and 2 study colonies; Canada and Greenland represented by 1 colony each (respectively Coats and Kippaku)

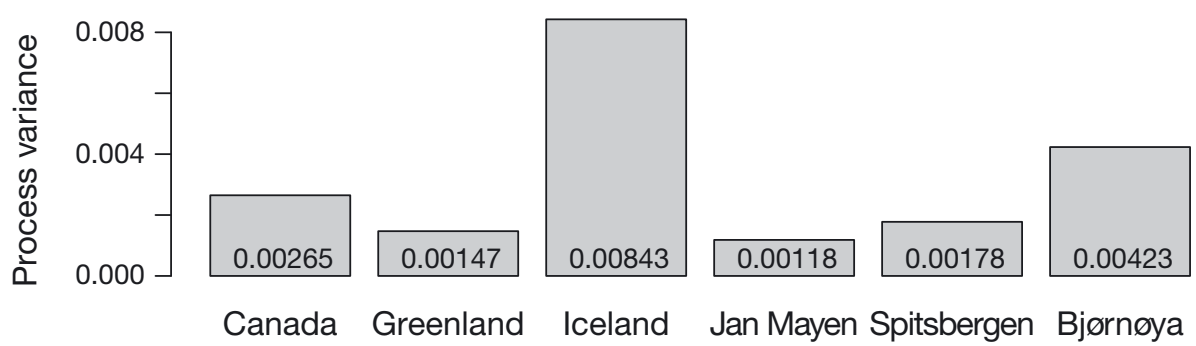

1.02 at Kippaku and 0.93 at Apparsuit, 2 colonies located $<10 \mathrm{~km}$ apart. Observed growth rates also differed substantially among colonies in Iceland, but less so in Spitsbergen. 


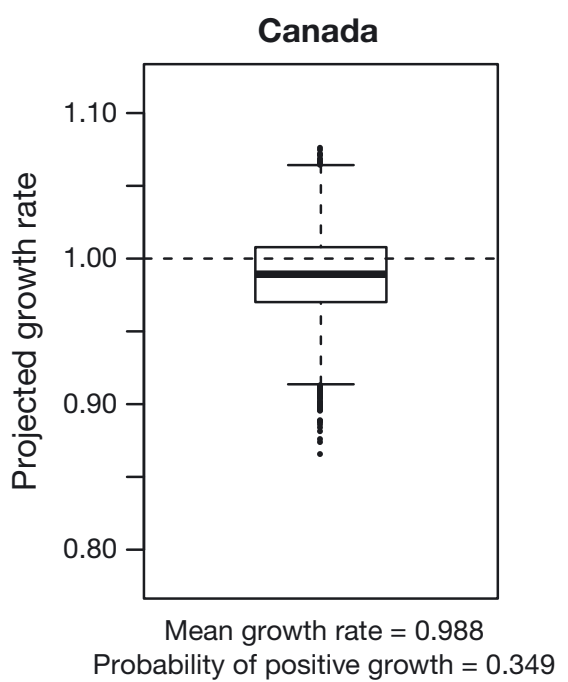

Greenland

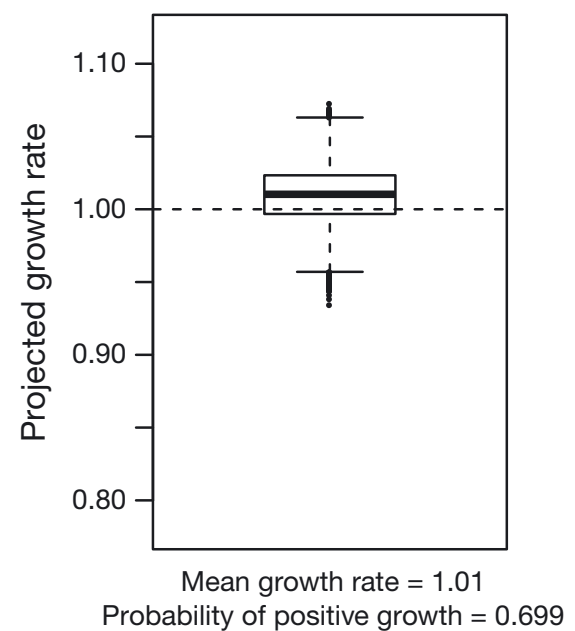

Iceland

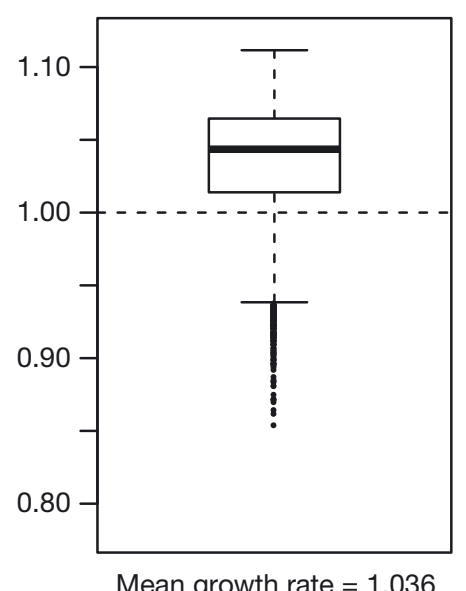

Probability of positive growth $=0.828$

Jan Mayen

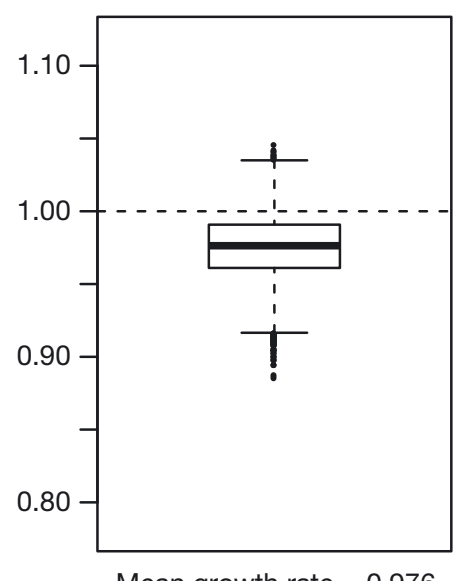

Probability of positive growth $=0.134$

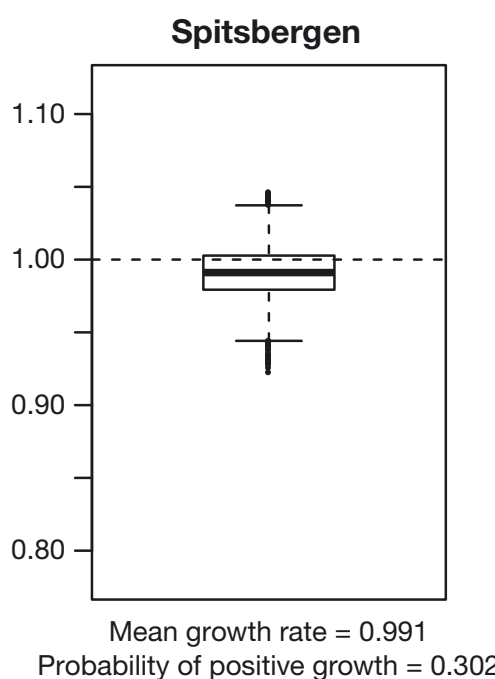

Bjørnøya

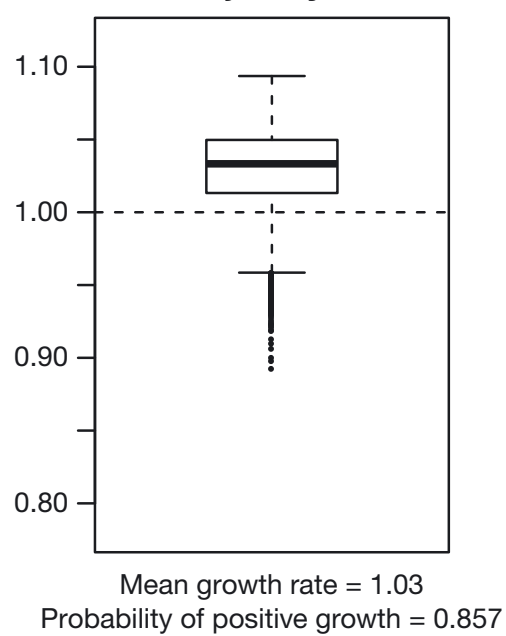

Fig. 4. Estimated stochastic population growth rate of thick-billed murres in the 6 regions under the basic scenario. Box plots: distribution of the 10000 simulations; horizontal dashed line: growth rate of 1, i.e. a stable population; box limits: lower to upper quartile; bold line: median; whiskers: $1.5 \times$ the interquartile range; dots: outliers. Models for Greenland, Iceland and Spitsbergen based on demographic data from respectively 3, 4 and 2 study colonies; Canada represented by 1 colony (Coats)

Table 3. The 3 survival models fitted to each thick-billed murre resighting data set. $\triangle$ QAIC $_{\mathrm{c}}$ : quasi-Akaike's information criterion corrected for small sample size and overdispersion, relative to the 'best' model among the three. Dashes: for Iceland and Jan Mayen, data were only available for 1 decade (2010s). Rightmost column: amount of between-year variation explained by decadal model, derived using analysis of deviance (Skalski et al. 1993)

\begin{tabular}{|c|c|c|c|c|}
\hline \multirow[t]{2}{*}{ Colony } & \multicolumn{3}{|c|}{ Survival model $\Delta \mathrm{QAIC}_{\mathrm{c}}$} & \multirow{2}{*}{$\begin{array}{l}\text { \% Variation } \\
\text { explained by } \\
\text { decadal mode }\end{array}$} \\
\hline & Constant & Decadal & Yearly & \\
\hline Canada/Coats & 31.0 & 30.2 & 0 & 5.9 \\
\hline Greenland/Kippaku & 0 & 2 & 8.3 & 1.1 \\
\hline Iceland & 0 & - & 1.9 & - \\
\hline Jan Mayen & 0 & - & 3.3 & - \\
\hline Spitsbergen/Diabasodden & 8.2 & 0 & 7.6 & 40.4 \\
\hline Spitsbergen/Ossian Sarsfjellet & $\mathrm{t} \quad 2.7$ & 4.8 & 0 & 0.0 \\
\hline Bjørnøya & 68.8 & 0 & 8.5 & 61.5 \\
\hline
\end{tabular}

\section{DISCUSSION}

We have collated and analysed the most extensive data set to date on spatiotemporal variation in demography of thick-billed murres. While adult survival showed only minor regional variation, breeding success was more variable. Observed colony growth rates were also variable, and in most cases lower than expected, given our estimates of breeding success and survival. Overall, the observed values of survival and breeding success are in accordance with previously published studies (Gaston et al. 1994, Sandvik et al. 


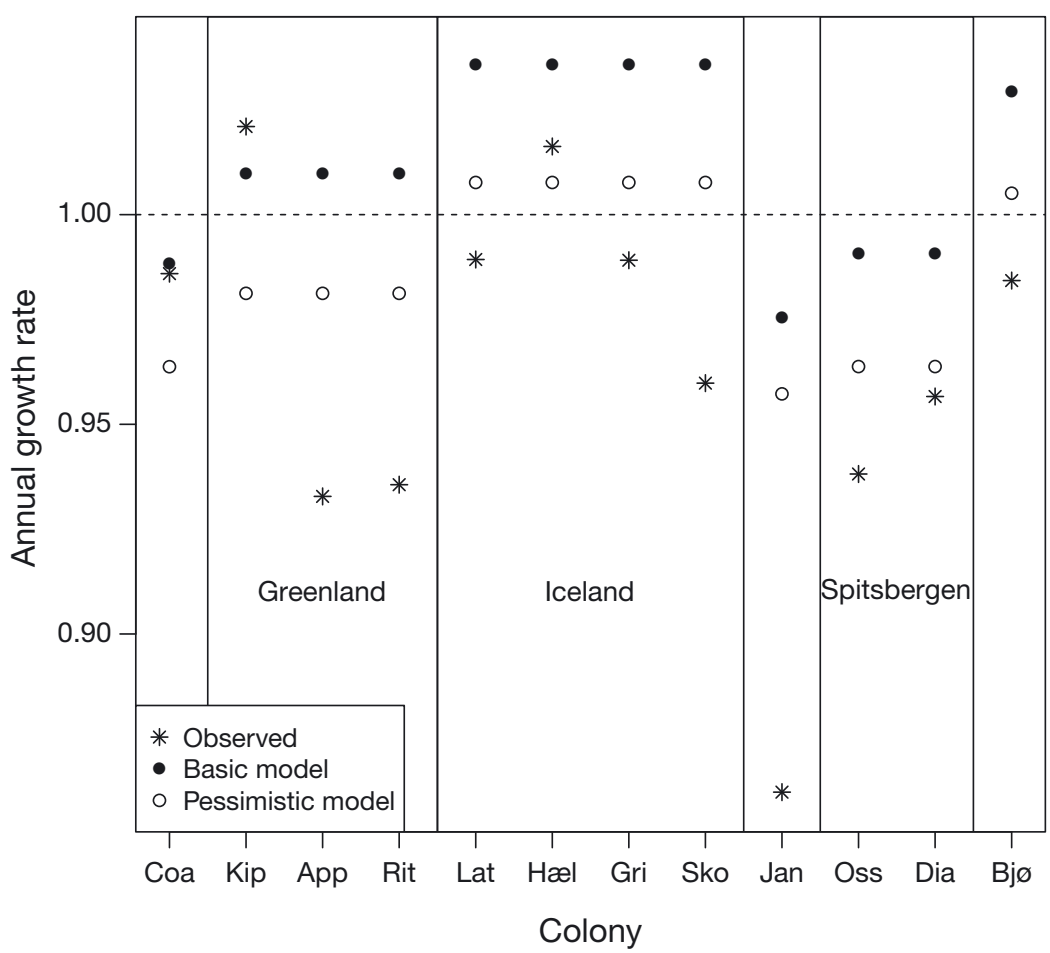

Fig. 5. Comparison of observed and modelled growth rates of thick-billed murre study colonies for the 2010s. Colonies ordered from west to east, with codes based on first 3 letters of colony names (Table 1). Modelled growth rates refer to the 6 regions, while observed growth rates refer to the 12 study colonies. Dashed horizontal line: growth rate of 1, i.e. a stable population

Mean adult survival showed relatively little variation among colonies (Fig. 3), and in most colonies, variation over longer (decadal) time scales was modest (Table 3, Fig. S2). The main exception was Bjørnøya, where our results indicate a major improvement in survival after 2010, following the very low values recorded in the 2000s (Fig. S2). Fluhr et al. (2017) showed that murre survival at Bjørnøya up to 2011 was correlated with fluctuation in the Subpolar Gyre. We have not updated this analysis with the longer time series, partly because of the recent scientific debate over the choice of Subpolar Gyre index (Foukal \& Lozier 2017, Koul et al. 2020). However, several of the candidate indices show a switch of sign after 2010 (Koul et al. 2020, their Fig. 3), which would be consistent with the improved survival of Bjørnøya murres.

The projected growth rates from our regional population models were in most cases higher than the observed growth rates, at least for the basic scenario with optimistic values of non-

2005). Mean breeding success in our Atlantic study colonies was generally higher than in Alaska, where complete breeding failures are sometimes observed and long-term colony means range from 0.25 to 0.65 chicks fledged per nest site (Dragoo et al. 2019). Estimated breeding success in Greenland and Iceland was very high, but similar values were recorded at Prince Leopold Island in the Canadian high Arctic in the 1970s (Gaston \& Nettleship 1981), and in other older studies in Arctic Canada and Greenland (summarised in Gaston et al. 1994). The high variance in breeding success at Coats was due to predation by polar bears Ursus maritimus and parasitism by mosquitoes (Gaston \& Elliott 2013). In years when a polar bear fed in the colony, all eggs and chicks in large areas of the colony, including several study plots, were destroyed. In years when mosquito activity was intense, many pairs in particular parts of the colony did not reproduce. Mean breeding success was very low at Jan Mayen. The reasons for this are unclear, but may be related to the topography of the study plots, which only allows small groups of murres to nest together. These small groups may be more vulnerable to the combination of investigator disturbance and predation by glaucous gulls Larus hyperboreus (Gilchrist \& Gaston 1997). observed vital rates (Fig. 5). This implies that our estimates of breeding success (Fig. 2) or adult survival (Fig. 3) are biased high, that our assumed values of other demographic variables (Table 2) are too optimistic, or that positive between-year covariance among vital rates (which we did not take into account in our model) reduced population growth rates (Fieberg \& Ellner 2001, Doak et al. 2005). Breeding success may be biased high in observational studies because not all breeding attempts can be followed from egg-laying until departure. On the other hand, investigator disturbance may cause a negative bias (Cairns 1980). Bias in estimates of breeding success or adult survival could also occur if the study plots are unrepresentative of the colonies. Intra-colony variation in demographic performance has previously been demonstrated in murres as well as in other seabird species (Gaston \& Nettleship 1981, Harris 1987, Descamps et al. 2009), and if high-quality areas are overrepresented in study plots, this could lead to a positive bias in parameter estimates. Positive bias in total fertility (the product of breeding propensity and breeding success) could also occur if breeding propensity declines and mainly high-quality birds remain in the colony, while low-quality birds 
(with potentially lower survival probability) abstain from breeding (Lescroël et al. 2009). On the other hand, colour-ringing usually takes place in peripheral parts of colonies, which could be predominantly occupied by lower-quality birds (Coulson 1968). Positive covariance between survival of different age classes is likely, because they are affected by the same environmental conditions through most of the year. However, we have no empirical information to quantify covariance.

On the larger scale, it is striking that only 2 colonies in the western part of the range (Coats Island in Canada and Kippaku in Greenland) had observed growth rates close to or above those expected under the basic scenario, whereas all colonies in Iceland, Jan Mayen, Spitsbergen and Bjørnøya declined faster than expected under this scenario (Fig. 5). Earlier studies showed positive growth of murre colonies in the Canadian Arctic (incl. Coats) during 1976-2000 (Gaston 2002), and pre-breeding survival at Coats appeared to be very high during this period (Gaston et al. 1994). This strongly suggests that either prebreeding survival (from 'fledging' to recruitment) or breeding propensity (age-specific proportions of breeders) was lower for eastern murre populations. These eastern populations, most of which are declining, overwinter mainly off Southwest Greenland and around Iceland, whereas the more stable western populations winter off Labrador and Newfoundland (Frederiksen et al. 2016). In the case of Jan Mayen, the observed colony growth rate $(0.862)$ was lower than mean estimated adult survival (0.903), implying that little or no recruitment of new breeders has taken place during the 2010s. Previous work has suggested that failing recruitment is one of the main drivers of the observed synchronised decline in Spitsbergen murre colonies (Descamps et al. 2013), possibly linked to fluctuations of the Subpolar Gyre, the main multiannual pattern of oceanographic variation in the wintering area of Spitsbergen murres (Hátún et al. 2005). There is no direct evidence of the timing of or mechanisms behind increased mortality before the age of recruitment, but one period of elevated vulnerability to e.g. low prey availability could be during and after the transition from paternal post'fledging' care to independence in autumn (approx. $37 \mathrm{~d}$ after leaving the colony, Elliott et al. 2017). Major mortality events (wrecks) of murres are occasionally reported in Southwest Greenland and Iceland, and the available evidence suggests that the cause of mortality is starvation (Nielsen \& Einarsson 2004, F. R. Merkel unpubl. data). In Greenland, approx. $50 \%$ of individuals affected by wrecks in 2003 ,
2014 and 2018 were first-winter birds and $75 \%$ were females, whereas most murres recorded during a wreck in Iceland in 2001/02 were adults with a surplus of males (Nielsen \& Einarsson 2004, F. R. Merkel unpubl. data). However, there is so far no direct evidence linking such wrecks to declines in specific colonies or populations.

Variation in recruitment to the breeding population or in breeding propensity of established breeders could be an important driver of population growth rate, and thus contribute to the mismatch between observed and modelled colony growth rates (Jenouvrier et al. 2005). Breeding propensity could be linked to variation in prey availability during spring. Results from Spitsbergen indeed suggest that poor environmental conditions (i.e. low sea-ice extent) around the colonies in the spring were associated with lower population size (Descamps \& Ramirez 2021). The proposed mechanism was that poor conditions affected food availability (and notably polar cod Boreogadus saida abundance) in the spring negatively, resulting in a lower breeding propensity of murres. This is similar to the pattern observed for common eiders Somateria mollissima feeding on blue mussels Mytilus spp. by Jean-Gagnon et al. (2018). Increased disturbance by predators like polar bears, possibly linked to climate change, could also affect breeding propensity negatively.

Previous work has shown that while legal harvest of murres in Canada and Greenland has a measurable impact on population growth in all breeding areas, this impact is insufficient to explain the rapid declines observed in the eastern populations (Frederiksen et al. 2019). Our results support this and show that these declines cannot be explained by low adult survival or breeding success (unless our estimates are strongly biased high), implying that the demographic mechanism responsible is either low pre-breeding survival or low breeding propensity (or a combination of the two). Post-fledging survival has been shown to be independent of body condition at fledging in common murres (Harris et al. 2007), most likely due to extended paternal care, and conditions around independence (approx. mid-September, Elliott et al. 2017) are presumably critical for survival. Prebreeding survival and breeding propensity are most likely primarily affected by feeding conditions during the non-breeding season, which again is likely to be mainly driven by oceanographic variability (Descamps et al. 2013). This leaves wildlife management agencies with few options for reversing the observed declines, other than reducing or eliminating any anthropogenic mortality due to hunting, oil 
spills or bycatch in fishing gear, and minimising human disturbance of breeding colonies. Although we found that both adult survival and breeding success were generally high (except breeding success at Jan Mayen), further improvements in these demographic parameters will partly offset the declines due to low pre-breeding survival or breeding propensity.

Overall, the consistent discrepancy between observed and modelled growth rates in populations breeding east of Greenland (Fig. 5) suggests that large-scale variation in population growth rate in Atlantic thick-billed murres is strongly related to post-breeding and/or wintering areas, as proposed by Frederiksen et al. (2016). Populations wintering off Newfoundland and Labrador may have higher pre-breeding survival than those wintering around Iceland and off Southwest Greenland and are thus able to maintain a higher population growth rate. The 2 main wintering areas are influenced by different oceanographic patterns. Biological productivity and species distributions in the Iceland-Greenland wintering area is strongly influenced by the balance between the warm Irminger Current and the cold East Greenland Current, which again is related to the strength of the Subpolar Gyre (Hátún et al. 2016, Post et al. 2021). The Newfoundland-Labrador Shelf ecosystem is mainly influenced by the cold Labrador Current, particularly in winter (Han et al. 2008). Contrasting population trends between murres breeding in the eastern and western Atlantic, probably related to large-scale atmospheric variation, have been noted previously by Irons et al. (2008). Fluctuations in large-scale ocean currents may thus have profound impacts on spatial variation in population trends of widely distributed marine predators. Our finding that among-region differences in growth rate of thick-billed murre colonies seem to be mainly driven by conditions in the non-breeding areas also supports Lack's (1966, see also Cairns 1992) hypothesis that seabird population size is largely regulated by food availability during the non-breeding season. However, prey availability during the breeding season may still be the main factor limiting the size of individual seabird colonies (Ashmole 1963).

Acknowledgements. The work in Svalbard (Bjørnøya and Spitsbergen) and Jan Mayen was funded by the Norwegian Polar Institute (MOSJ programme, www.mosj.no) and the Norwegian seabird monitoring programme SEAPOP (www. seapop.no; grant number 192141). Fieldwork in Greenland was supported by the Greenland Government. The monitoring programme in Iceland was supported by the Icelandic Ministry for the Environment and Natural Resources. We thank the numerous field assistants who helped in collecting these long-term monitoring data every summer.

\section{LITERATURE CITED}

Albert C, Helgason HH, Brault-Favrou M, Robertson GJ and others (2021) Seasonal variation of mercury contamination in Arctic seabirds: a pan-Arctic assessment. Sci Total Environ 750:142201

Anker-Nilssen T, Barrett RT, Lorentsen SH, Strøm H and others (2015) SEAPOP: de ti første årene, nøkkeldokument 2005-2014. SEAPOP, Norsk Institutt for Naturforskning, Norsk Polarinstitutt \& Tromsø Museum, Trondheim, Tromsø

Ashmole NP (1963) The regulation of numbers of tropical oceanic birds. Ibis 103b:458-473

Birt VL, Birt TP, Goulet D, Cairns DK, Montevecchi WA (1987) Ashmole's halo: direct evidence for prey depletion by a seabird. Mar Ecol Prog Ser 40:205-208

* Bjørnstad ON, Ims RA, Lambin X (1999) Spatial population dynamics: analyzing patterns and processes of population synchrony. Trends Ecol Evol 14:427-432

Cairns DK (1980) Nesting density, habitat structure and human disturbance as factors in Black Guillemot reproduction. Wilson Bull 92:352-361

Cairns DK (1992) Population regulation of seabird colonies. Curr Ornithol 9:37-61

Caswell H (2001) Matrix population models. Construction, analysis, and interpretation. Sinauer, Sunderland, MA

* Cayuela H, Griffiths RA, Zakaria N, Arntzen JW and others (2020) Drivers of amphibian population dynamics and asynchrony at local and regional scales. J Anim Ecol 89: 1350-1364

Choquet R, Lebreton JD, Gimenez O, Reboulet AM, Pradel R (2009) U-CARE: utilities for performing goodness of fit tests and manipulating CApture-REcapture data. Ecography 32:1071-1074

Coulson JC (1968) Differences in the quality of birds nesting in the centre and on the edges of a colony. Nature 217: 478-479

*Dallimer M, Strange N (2015) Why socio-political borders and boundaries matter in conservation. Trends Ecol Evol 30:132-139

* Descamps S, Ramirez F (2021) Species and spatial variation in the effects of sea-ice on Arctic seabird populations. Divers Distrib, doi:10.1111/ddi.13389

Descamps S, Le Bohec C, Le Maho Y, Gendner JP, GauthierClerc M (2009) Relating demographic performance to breeding-site location in the king penguin. Condor 111: 81-87

* Descamps S, Strøm H, Steen H (2013) Decline of an Arctic top predator: synchrony in colony size fluctuations, risk of extinction and the subpolar gyre. Oecologia 173:1271-1282

* Descamps S, Merkel B, Strøm H, Choquet R and others (2020) Sharing wintering grounds does not synchronize annual survival in a high Arctic seabird, the little auk. Mar Ecol Prog Ser: SEAav1. doi:10.3354/meps13400

* Doak DF, Morris WF, Pfister C, Kendall BE, Bruna EM (2005) Correctly estimating how environmental stochasticity influences fitness and population growth. Am Nat 166: E14-E21

Dragoo DE, Renner HM, Kaler RSA (2019) Breeding status and population trends of seabirds in Alaska, 2018. US Fish and Wildlife Service, Homer, AK

* Ekroos J, Öst M, Karell P, Jaatinen K, Kilpi M (2012) Philopatric predisposition to predation-induced ecological traps: habitat-dependent mortality of breeding eiders. Oecologia 170:979-986 
Elliott KH, Woo KJ, Gaston AJ, Benvenuti S, Dall'Antonia L, Davoren GK (2009) Central-place foraging in an Arctic seabird provides evidence for Storer-Ashmole's halo. Auk 126:613-625

Elliott KH, Linnebjerg JF, Burke C, Gaston AJ, Mosbech A, Frederiksen M, Merkel F (2017) Variation in growth drives the duration of parental care: a test of Ydenberg's model. Am Nat 189:526-538

Ens BJ, Kersten M, Brenninkmeijer A, Hulscher JB (1992) Territory quality, parental effort and reproductive success of oystercatchers (Haematopus ostralegus). J Anim Ecol 61:703-715

Fieberg J, Ellner SP (2001) Stochastic matrix models for conservation and management: a comparative review of methods. Ecol Lett 4:244-266

Fluhr J, Strøm H, Pradel R, Duriez O, Beaugrand G, Descamps S (2017) Weakening of the subpolar gyre as a key driver of North Atlantic seabird demography: a case study with Brünnich's guillemots in Svalbard. Mar Ecol Prog Ser 563:1-11

Foukal NP, Lozier MS (2017) Assessing variability in the size and strength of the North Atlantic subpolar gyre. J Geophys Res Oceans 122:6295-6308

Frederiksen M, Harris MP, Wanless S (2005) Inter-population variation in demographic parameters: a neglected subject? Oikos 111:209-214

Frederiksen M, Descamps S, Erikstad KE, Gaston AJ and others (2016) Migration and wintering of a declining seabird, the thick-billed murre Uria lomvia, on an ocean basin scale: conservation implications. Biol Conserv 200: 26-35

Frederiksen M, Linnebjerg JF, Merkel FR, Wilhelm SI, Robertson GJ (2019) Quantifying the relative impact of hunting and oiling on Brünnich's guillemots in the North-west Atlantic. Polar Res 38:3378

Garðarsson A, Guðmundsson GA, Lilliendahl K (2019) Svartfugl í íslenskum fuglabjörgum 2006-2008. Bliki 33: $35-46$

Gaston AJ (2002) Results of monitoring thick-billed murre populations in the eastern Canadian Arctic, 1976-2000. Can Wildl Serv Occas Pap 106:13-48

Kaston AJ (2003) Synchronous fluctuations of Thick-billed Murre (Uria lomvia) colonies in the eastern Canadian Arctic suggest population regulation in winter. Auk 120: 362-370

Gaston AJ, Elliott KH (2013) Effects of climate-induced changes in parasitism, predation and predator-predator interactions on reproduction and survival of an Arctic marine bird. Arctic 66:43-51

Gaston AJ, Hipfner JM (2020) Thick-billed Murre (Uria lomvia), version 1.0. In: Billerman SM (ed) Birds of the world. Cornell Lab of Ornithology, Ithaca, NY

Gaston AJ, Jones IL (1998) The auks. Oxford University Press, Oxford

Gaston AJ, Nettleship DN (1981) The thick-billed murres of Prince Leopold Island. Canadian Wildlife Service, Ottawa

Gaston AJ, de Forest LN, Gilchrist G, Nettleship DN (1993) Monitoring thick-billed murre populations at colonies in northern Hudson Bay, 1972-1992. Can Wildl Serv Occas Pap 80

Gaston AJ, Forest LN, Donaldson G, Noble DG (1994) Population parameters of thick-billed murres at Coats Island, Northwest Territories, Canada. Condor 96:935-948

* Gilchrist HG, Gaston AJ (1997) Effects of murre nest site characteristics and wind conditions on predation by glaucous gulls. Can J Zool 75:518-524

* Gimenez O, Choquet R, Lebreton JD (2003) Parameter redundancy in multistate capture-recapture models. Biom J 45:704-722

Gould WR, Nichols JD (1998) Estimation of temporal variability of survival in animal populations. Ecology 79 : 2531-2538

Han GQ, Lu ZS, Wang ZL, Helbig J, Chen N, de Young B (2008) Seasonal variability of the Labrador Current and shelf circulation off Newfoundland. J Geophys Res Oceans 113:C10013

Harris MP (1987) A low-input method of monitoring kittiwake Rissa tridactyla breeding success. Biol Conserv 41: $1-10$

Harris MP, Wanless S, Barton TR (1996) Site use and fidelity in the Common Guillemot Uria aalge. Ibis 138:399-404

* Harris MP, Frederiksen M, Wanless S (2007) Within- and between-year variation in the juvenile survival of Common Guillemots Uria aalge. Ibis 149:472-481

Harrison AL, Costa DP, Winship AJ, Benson SR and others (2018) The political biogeography of migratory marine predators. Nat Ecol Evol 2:1571-1578

KHátún H, Sandø AB, Drange H, Hansen B, Valdimarsson H (2005) Influence of the Atlantic subpolar gyre on the thermohaline circulation. Science 309:1841-1844

*Hátún H, Lohmann K, Matei D, Jungclaus JH and others (2016) An inflated subpolar gyre blows life toward the northeastern Atlantic. Prog Oceanogr 147:49-66

* Irons DB, Anker-Nilssen T, Gaston AJ, Byrd GV and others (2008) Fluctuations in circumpolar seabird populations linked to climate oscillations. Glob Change Biol 14: 1455-1463

Jean-Gagnon F, Legagneux P, Gilchrist G, Belanger S, Love O, Bêty J (2018) The impact of sea ice conditions on breeding decisions is modulated by body condition in an Arctic partial capital breeder. Oecologia 186:1-10

Jenouvrier S, Barbraud C, Cazelles B, Weimerskirch H (2005) Modelling population dynamics of seabirds: importance of effects of climate fluctuations on breeding proportions. Oikos 108:511-522

Jenouvrier S, Thibault JC, Viallefont A, Vidal P and others (2009) Global climate patterns explain range-wide synchronicity in survival of a migratory seabird. Glob Change Biol 15:268-279

Johnson HE, Mills LS, Stephenson TR, Wehausen JD (2010) Population-specific vital rate contributions influence management of an endangered ungulate. Ecol Appl 20: 1753-1765

Koul V, Tesdal JE, Bersch M, Hátún H and others (2020) Unraveling the choice of the north Atlantic subpolar gyre index. Sci Rep 10:1005

Lack D (1966) Population studies of birds. Oxford University Press, Oxford

Lebreton JD, Burnham KP, Clobert J, Anderson DR (1992) Modeling survival and testing biological hypotheses using marked animals: a unified approach with case studies. Ecol Monogr 62:67-118

KLee DE, Bond ML, Kissui BM, Kiwango YA, Bolger DT (2016) Spatial variation in giraffe demography: a test of 2 paradigms. J Mammal 97:1015-1025

兴 Lescroël A, Dugger KM, Ballard G, Ainley DG (2009) Effects of individual quality, reproductive success and environmental variability on survival of a long-lived seabird. J Anim Ecol 78:798-806 
Liebhold A, Koenig WD, Bjørnstad ON (2004) Spatial synchrony in population dynamics. Annu Rev Ecol Evol Syst 35:467-490

Link WA, Nichols JD (1994) On the importance of sampling variance to investigations of temporal variation in animal population size. Oikos 69:539-544

Linnebjerg JF, Frederiksen M, Kolbeinsson Y, Snaethórsson AÖ, Thórisson B, Thórarinsson TL (2018) Non-breeding areas of three sympatric auk species breeding in three Icelandic colonies. Polar Biol 41:1951-1961

Merkel F, Labansen AL, Boertmann D, Mosbech A and others (2014) Declining trends in the majority of Greenland's thick-billed murre (Uria lomvia) colonies 19812011. Polar Biol 37:1061-1071

Merkel FR, Johansen KL, Kristensen AJ (2016) Use of timelapse photography and digital image analysis to estimate breeding success of a cliff-nesting seabird. J Field Ornithol 87:84-95

Nielsen ÓK, Einarsson Ó (2004) Svartfugladaudin mikli veturinn 2001-2002. Natturufraedingurinn 72:117-127

Norris K (2004) Managing threatened species: the ecological toolbox, evolutionary theory and declining-population paradigm. J Appl Ecol 41:413-426

Pironon S, Papuga G, Villellas J, Angert AL, Garcia MB, Thompson JD (2017) Geographic variation in genetic and demographic performance: new insights from an old biogeographical paradigm. Biol Rev Camb Philos Soc 92: 1877-1909

Post S, Werner KM, Núñez-Riboni I, Chafik L, Hátún $\mathrm{H}$, Jansen T (2021) Subpolar gyre and temperature drive boreal fish abundance in Greenland waters. Fish Fish 22: 161-174

Pradel R (1993) Flexibility in survival analysis from recapture data: handling trap-dependence. In: Lebreton JD, North PM (eds) Marked individuals in the study of bird population. Birkhäuser Verlag, Basel, p 29-37

R Core Team (2019) R: a language and environment for statistical computing. R Foundation for Statistical Computing, Vienna

Reneerkens J, Versluijs TSL, Piersma T, Alves JA and others (2020) Low fitness at low latitudes: wintering in the tropics increases migratory delays and mortality rates in an Arctic breeding shorebird. J Anim Ecol 89: 691-703

Editorial responsibility: Thierry Boulinier,

Montpellier, France

Reviewed by: D. Oro, N. Ratcliffe, C. Horswill
Ringsby TH, Sæther BE, Tufto J, Jensen H, Solberg EJ (2002) Asynchronous spatiotemporal demography of a house sparrow metapopulation in a correlated environment. Ecology 83:561-569

Sandvik H, Erikstad KE, Barrett RT, Yoccoz NG (2005) The effect of climate on adult survival in five species of North Atlantic seabirds. J Anim Ecol 74:817-831

Sanz-Aguilar A, Massa B, Lo Valvo F, Oro D, Minguez E, Tavecchia G (2009) Contrasting age-specific recruitment and survival at different spatial scales: a case study with the European storm petrel. Ecography 32:637-646

Skalski JR, Hoffmann A, Smith SG (1993) Testing the significance of individual- and cohort-level covariates in animal survival studies. In: Lebreton JD, North PM (eds) Marked individuals in the study of bird population. Birkhäuser Verlag, Basel, p 9-28

Strøm H, Descamps S, Bakken V (2008) Seabird colonies by the Barents Sea, White Sea and Kara Sea. Norwegian Polar Institute, Tromsø

* Stubben CJ, Milligan BG (2007) Estimating and analyzing demographic models using the popbio package in $\mathrm{R}$. J Stat Softw 22:11

Suryan RM, Saba VS, Wallace BP, Hatch SA, Frederiksen M, Wanless S (2009) Environmental forcing on life history strategies: evidence for multi-trophic level responses at ocean basin scales. Prog Oceanogr 81:214-222

* Tavecchia G, Minguez E, De Leon A, Louzao M, Oro D (2008) Living close, doing differently: small-scale asynchrony in demography of two species of seabirds. Ecology 89:77-85

Tjørnløv RS, Ens BJ, Öst M, Jaatinen K and others (2020) Drivers of spatiotemporal variation in survival in a flyway population: a multi-colony study. Front Ecol Evol 8:566154

Walsh PM, Halley DJ, Harris MP, del Nevo A, Sim IMW, Tasker ML (1995) Seabird monitoring handbook for Britain and Ireland. JNCC/RSPB/ITE/Seabird Group, Peterborough

White GC, Burnham KP (1999) Program MARK: survival estimation from populations of marked animals. Bird Study 46(Suppl):S120-S139

Wiese FK, Robertson GJ, Gaston AJ (2004) Impacts of chronic marine oil pollution and the murre hunt in Newfoundland on thick-billed murre Uria lomvia populations in the eastern Canadian Arctic. Biol Conserv 116:205-216

Submitted: February 4, 2021

Accepted: July 8, 2021

Proofs received from author(s): August 12, 2021 